
\title{
Research Suare \\ Different Driving Factors for Potential Activity of Ammonia-Oxidizing Archaea and Bacteria in Coastal Wetlands
}

Xianfang zhu ( $\nabla$ xf_zhu@126.com )

Peking University https://orcid.org/0000-0002-8795-2041

Chen Wang

Peking University

Shuangyu Tang

Peking University

Guodong Ji

Peking University

\section{Research Article}

Keywords: potential activity of $A O A$ and $A O B$, driving factors for $A O A$ and $A O B$, functional gene, nitrogen cycling

Posted Date: May 28th, 2021

DOl: https://doi.org/10.21203/rs.3.rs-280386/v1

License: (c) (i) This work is licensed under a Creative Commons Attribution 4.0 International License. Read Full License 


\section{Abstract}

This study aimed to evaluate which environmental factors and genetic groups were important in explaining measured activity of Ammonia-oxidizing archaea (AOA) and bacteria (AOB), which play important roles in global nitrogen cycle, providing a new insight into the mechanism of archaeal and bacterial ammonia oxidation. We sampled 62 soil/sediment samples from coastal wetlands of the Bohai area of China and assessed the abundance of functional genes involved in the nitrogen cycle, soil/sediment characteristics and the potential activity of $A O A$ (PAOA) and AOB (PAOB) using specific inhibitors. At last, we introduced the structure equation model (SEM) to infer direct and indirect effects of variables on potential activities. The results indicated that the change in AOA-amoA gene abundance may be more independent, while AOB-amoA was closely associated with the change in abundance of amx and denitrifier. PAOA was mainly defined by AOA-amoA abundance and partially influenced by the norA gene, suggesting coupling of archaeal ammonia oxidation with nitrite oxidation. PAOB was significantly defined by the abundance of $a m x$ and denitrifier, indirectly mediated by AOB-amoA. The activity of AOA seemed to be more independent of other microbial activities, while the activity of $A O B$ varied closely with fluctuations of other microbial species. PAOA was mediated directly by the $\mathrm{C} / \mathrm{N}$ ratio and indirectly by nitrite concentration and TOC value, while PAOB was mediated directly by ammonium concentration and TOC value and indirectly by $\mathrm{C} / \mathrm{N}$ ratio. The activity of $\mathrm{AOB}$ may be determined by several other functional gene groups and had little correlation with $A O B$ abundance while the activity of AOA was mostly controlled by itself.

\section{Introduction}

Increasing consumption of nitrogen fertilizer all around the world leads to global nitrogen overload and had been identified as a main emerging environmental issue in this century (Zheng et al. 2013). A largescale production of ammonia has been rising steadily $(+1.5 \% /$ year) to over $150 \mathrm{mT}$ every year and most of them are used to the production of ammonium fertilizer (Wendeborn 2019). Only 30-50\% of nitrogen is assimilated by crop plants while the remaining $50-70 \%$ goes into biological processes. In the processes mostly dominated by microorganisms, ammonia must be oxidized at least once before returning into atmosphere as $\mathrm{N}_{2}$ or $\mathrm{N}_{2} \mathrm{O}$ (Wang et al. 2014).

Ammonia oxidation is the first and rate-limiting step in nitrification as well as an essential part of the global nitrogen cycle (Kowalchuk and Stephen 2001; Pester et al. 2012). This process is important to nitrogen availability, nitrate leaching and nitrous oxide emission (Godde and Conrad 1999; Levy-Booth et al. 2014). For a long time, the process was thought to be driven only by AOB (Kowalchuk and Stephen 2001; Prosser and Nicol 2008). However, in the past decade, AOA (Hatzenpichler et al. 2008; Könneke et al. 2005; Venter et al. 2004) has been confirmed to be jointly responsible for ammonia oxidation along with AOB under aerobic conditions (Jia and Conrad 2009).

$A O A$ and $A O B$ had been found to co-exist in most ecosystems and may be influenced by various environmental factors (Erguder et al. 2009; Gleeson et al. 2010). The abundance and community of AOA 
and $A O B$ vary in different ecosystems and are easily influenced by soil conditions (Bouskill et al. 2012; Caffrey et al. 2007; Wuchter et al. 2006). Many previous studies have demonstrated the influence of environmental factors on ecological niche differentiation between $\mathrm{AOA}$ and $\mathrm{AOB}$ using cultivationindependent molecular methods. Researchers found that salinity (Caffrey et al. 2007), DO (Abell et al. 2011), pH value (Nicol et al. 2008; Wang et al. 2014; Ying et al. 2017) and N fertilizer (Glaser et al. 2010) had great influence on the abundance and community structure of $A O A$ and $A O B$ in different soil/sediment environments. However, most studies focused only on the gene abundance, expression or community structure of $\mathrm{AOA}$ and $\mathrm{AOB}$. Only a few researches reported the weak correlation between ammonia oxidation activity and $a m o A$ abundance for $A O A$ and $A O B$ (Hou et al. 2013). To date, there is no study reporting the quantitative response of $A O A$ and $A O B$ activity to multiple environmental factors and the driving factors for $A O A$ and $A O B$ activity remained unknown.

In addition, many studies showed that potential nitrogen cycling activities were controlled by the combination of various genetic groups and environmental factors (Guo et al. 2011; Siles et al. 2017; Zhang et al. 2017). For instance, the nitrification gene ratio and free ammonium may well explain nitrite and nitrous oxide production in urea-amended soils (Breuillin-Sessoms et al. 2017). And the complex genetic drivers are thought to be responsible for nitrogen removal in tidal flow constructed wetlands, which was the result of analysing the quantitative relationships between the rate of denitrification and nitrogen cycling gene groups (Zhi and Ji 2014). However, the associations between AOA/AOB and other nitrogen cycling microorganisms are poorly understood. It is very important for us to explore the driving factors, both genetic groups and environmental factors, for the activity of $A O A$ and $A O B$ to understand the archaeal and bacterial ammonia oxidation and the important step in the nitrogen cycle.

In this study, 62 samples from four typical wetlands along the Bohai area were collected. We measured the abundance of functional genes involved in the nitrogen cycle and the potential activities of $A O A$ and $A O B$ using antibiotic inhibitors. We used structure equation model (SEM) to infer direct and indirect effects of variables on potential activities to evaluate which environmental factors and genetic groups were important in explaining measured activity of AOA and AOB.

\section{Materials And Methods}

\subsection{Sampling}

A total of 62 soil/sediment samples across four typical wetlands were collected from coastal wetlands of the Bohai area in June 2012 (Fig. 1). The four wetlands are paddy fields (PF), estuary wetlands (EW), reed wetlands (RW) and shallow wetlands (SW). Paddy fields are the wetlands people farm and fertilize, which are influenced most by human activity. Estuary wetlands are the wetlands near estuary where rivers and the inside pollutants going into the sea. The other two wetlands are influenced less by human activity, reed wetlands covered by reeds while shallow wetlands with little vegetation but shallow seawater. The specific information of the 62 samples were listed in Table 1. At each sampling site, triplicate samples were collected from the top $10 \mathrm{~cm}$ with PVC tubes and then composited into one per site. The samples 
were placed in sterile plastic bags, which were sealed and transported to the laboratory on ice. Each sample was divided to three subsamples, one subsample incubated to determine the potential ammonia oxidation activity of $\mathrm{AOA}$ and $\mathrm{AOB}$ while another processed through a 2.0-mm sieve for subsequent analysis of the physical-chemical components. The remainder was stored at $-80^{\circ} \mathrm{C}$ for DNA extraction and molecular analysis.

\subsection{Sediment physiochemical characteristics}

Approximately $10.0 \mathrm{~g}$ samples were extracted using $100 \mathrm{~mL}$ of $2 \mathrm{M} \mathrm{KCl}$. The solution after filtration was used to analyse nitrate nitrogen $\left(\mathrm{NO}_{3}{ }^{-}-\mathrm{N}\right)$, nitrite nitrogen $\left(\mathrm{NO}_{2}{ }^{-} \mathrm{N}\right)$ and ammonium nitrogen $\left(\mathrm{NH}_{4}{ }^{+}-\mathrm{N}\right)$ by a continuous flow analyser (TRRACS, Bran + Luebbe, Norderstedt, Germany). The $\mathrm{pH}$ of the soil/water suspensions was measured (1/2.5 w/v) (Hou et al. 2013), and the total organic carbon (TOC) was determined using an elemental analyser (2400II CHNS/O, PerkinElmer, USA).

\subsection{Potential ammonia oxidation activity}

The ammonia oxidation rates of $A O A$ and $A O B$ were measured in three replicates with two sets of experiments (groups $A$ and $B$ ). The homogenized, field-moist soil/sediment samples $(10.0 \mathrm{~g})$ were weighed into $150-\mathrm{mL}$ incubation flasks, and $80 \mathrm{~mL}$ of solution $(0.4 \mathrm{~g} / \mathrm{L} \mathrm{MgCl} 2,0.5 \mathrm{~g} / \mathrm{L} \mathrm{KCl}, 0.2 \mathrm{~g} / \mathrm{L}$ $\mathrm{KH}_{2} \mathrm{PO}_{4}, 1 \mathrm{~g} / \mathrm{L} \mathrm{NaCl}, 0.1 \mathrm{~g} / \mathrm{L} \mathrm{CaCl}_{2}$, and $10 \mathrm{mM} \mathrm{KClO}_{3}$; Fisher Scientific) was added to each replicate. Additional, a final concentration of $100 \mathrm{mg} / \mathrm{L}$ streptomycin sulfate was added to group $B$ to inhibit the activity of bacteria. After one-day pre-incubation, a final concentration of $0.5 \mathrm{mM}$ ammonium chloride was added to all groups. The flasks were incubated at $30^{\circ} \mathrm{C}$ in an orbital shaker, and the mud was sampled every 24 hours to define the total ammonia oxidation rate (group A) and the archaeal ammonia oxidation rate (group B) through analyses of nitrite concentration changes. The bacterial ammonia oxidation rate was determined by subtracting group $B$ from group $A$.

\subsection{DNA extraction and quantitative PCR}

DNA was extracted from $0.5 \mathrm{~g}$ of each soil/sediment sample using a Fast DNA SPIN Kit for Soil (MP Biomedicals, Santa Ana, CA) in accordance with the manufacturer's instructions. The three extracts from the same replicate plot were pooled before further analysis. DNA concentration and quality were measured using a NanoDrop ND-1000 spectrophotometer (Thermo Scientific, Wilmington, DE, USA).

Several genes were used to assess the abundance of different functional groups of $\mathrm{N}$ cycling microorganisms. The AOA-amoA, AOB-amoA and norA genes were used to quantify archaeal and bacterial ammonia oxidizers and nitrifiers, respectively. The amx gene, biomarker of anaerobic ammonia oxidation process, was used to quantify anaerobic ammonia oxidizers. The membrane-bound nitrate reductase gene ( $n a r G$ ) and periplasmic nitrate reductase gene (napA) were used to quantify nitrate reducers. The cytochrome cd1-containing nitrite reductase gene (nirS), Cu-containing nitrite reductase gene (nirK), nitric oxide reductase gene ( $q$ nor $B$ ) and nitrous oxide reductase gene (nosZ) were used to quantify groups of denitrifiers. Amplification was performed in triplicate with an ABI PRISM 7300 (Applied Biosystems, USA) using a 20- $\mu \mathrm{L}$ reaction mixture including $10 \mu \mathrm{L}$ Power SYBR Green Mixture (Applied 
Biosystems, USA), $4 \mu \mathrm{L}$ primer pairs, $1.0 \mu \mathrm{L}$ template DNA and $1 \mu \mathrm{L}$ PCR grade MQ-water (MP Biomedicals). Specific primer combinations and thermal cycling conditions used for each reaction are listed in Table 2 and Table 3. Standard curves were obtained using serial dilutions of linearized plasmids containing targeted genes. Sterile water was used as a negative control to detect and exclude any possible contamination or carryover.

\subsection{Statistical analyses}

The structure equation model (SEM) was introduced to infer direct and indirect effects of variables on potential activities (Fox 2006). To determine whether the further addition or removal of paths would improve model accuracy, we used modification indices in the R package. The model fit was evaluated using the Chi-square goodness-of-fit $\left(\chi^{2}\right)$, Tucker-Lewis non-normed fit index (NNFI), Akaike information criterion (AIC), and root mean square error of approximation (RMSEA) (Hershberger 2001). A nonsignificant $P$-value $(P>0.05)$ for the Chi-square statistic indicates no significant difference in the covariance pattern predicted by the SEM and from the observed covariance, which indicates good fit of the data. We fitted the SEMs as linear models and reported the standardized coefficient for each path. The importance of an explanatory variable was based on its total effect, which was the sum of direct and indirect effects on the response variable (Wootton 1994). Data processing and analysis were performed with SPSS Statistics 20 (IBM, USA). A priori P-value of $\mathrm{P}<0.05$ was defined to test significant difference.

\section{Results}

\subsection{Abundance of nitrogen cycling functional genes}

The abundances of the ten tested functional genes involved in the nitrogen cycle (namely, amx, AOAamoA, AOB-amoA, norA, narG, napA, nirS, nirk, nosZ and qnorB) in all 62 wetland samples are shown in Fig. 2. The average abundance of the amx gene was about $5.0 \times 10^{8}$ copies $/ \mathrm{g}$. AOA-amoA was numerically dominant over $\mathrm{AOB}-\mathrm{amoA}$, with one order of magnitude higher abundance. The abundance of nirK was close to that of nirS, at $1.15 \times 10^{8}$ and $2.97 \times 10^{8}$ copies $/ g$, respectively. The abundances of nos $Z$ and qnor $B$ varied insignificantly among all samples (approximately $10^{7} \mathrm{copies} / \mathrm{g}$ ). The abundance of napA was higher than that of narG.

All functional genes could be divided into six genetic groups, which presented six different nitrogen transferring processes. The $a m x, \mathrm{AOA}-\mathrm{amoA}, \mathrm{AOB}-\mathrm{amoA}$, and norA genes represented anaerobic ammonia oxidation, archaeal ammonia oxidation, bacterial ammonia oxidation and nitrite oxidation, respectively. The summation of narG and napA represented nitrate reduction, and the summation of nirk, nirS, qnorB and nos $Z$ represented denitrification. The gene abundance of each process is shown in Fig. 3 . The gene abundances of anaerobic ammonia oxidation, denitrification and nitrate reduction were relatively higher, at $2 \sim 3$ orders of magnitude, than archaeal ammonia oxidation, bacterial ammonia oxidation and nitrite oxidation. 


\subsection{Cluster analysis based on functional gene groups involved in nitrogen cycle}

All samples could be divided into six clusters (clusters A, B, C, D, E and F) according to heat map analysis based on the abundance of functional gene groups involved in different nitrogen cycle processes, and the results are shown in Fig. 4. The samples in each cluster mean that they have the most similarity of gene abundance composition, and each cluster had its characteristic gene abundance composition. Cluster $\mathrm{A}$ contained 3 samples from EWs and SWs, all with relatively higher abundance of the norA gene than others. Cluster B contained 21 samples mainly from EWs, all with relatively higher abundance of the AOAamoA gene than others. Cluster $\mathrm{C}$ contained 17 samples mainly from EWs and SWs, all with relatively higher abundance of denitrifier (represented by accumulation of nirK, nirS, nos $Z$ and qnorB gene) than others. Cluster D contained 7 samples mainly from EWs, all with relatively higher abundance of the AOB$a m o A$ gene than others. Cluster E contained 3 samples from EWs and SWs, all with relatively higher abundance of nitrate-reducing communities (represented by accumulation of narG and napA gene) than others. Cluster $\mathrm{F}$ contained 11 samples mainly from EWs and RWs, all with relatively higher abundance of both the amx and norA genes than others.

The abundance of functional gene groups in each cluster is shown in Fig. 5. Cluster A has the highest abundance of norA gene, with an average value of $1.88 \times 10^{7}$ copies $/ g$, which was 2 orders of magnitude higher than that of other clusters. In cluster $\mathrm{B}$, the average abundance of AOA-amoA gene was $7.50 \times 10^{7}$ copies/g, which was approximately 6 - to 20 -fold greater than that of other clusters. Cluster $\mathrm{C}$ has the highest abundance of gene groups responsible for denitrification, with an average value of $8.59 \times 10^{8}$ copies $/ \mathrm{g}$. In cluster $\mathrm{D}$, the average abundance of AOB-amoA was $1.15 \times 10^{7} \mathrm{copies} / \mathrm{g}$, which was approximately 2- to 15-fold greater than that of the other clusters. Cluster $E$ has the highest abundance of nitrate-reducing genes, with an average value of $1.09 \times 10^{9}$ copies $/ \mathrm{g}$, which was $1 \sim 2$ orders of magnitude greater than that of the other clusters.

\subsection{Potential ammonia oxidation activity}

The potential ammonia oxidation activity of $A O A$ (PAOA) ranged from 0.01 to $6.26 \mu \mathrm{g} \mathrm{N} \mathrm{g}^{-1} \mathrm{~d}^{-1}$, while the potential activity of $A O B$ (PAOB) ranged from 0.01 to $26.24 \mu \mathrm{g} \mathrm{N} \mathrm{g}^{-1} \mathrm{~d}^{-1}$. AOA contributed approximately $0.46-83.21 \%$ to ammonia oxidation across the landscape, while the remainder was attributed to $A O B$.

The activity of ammonia oxidation driving by AOA was markedly higher in samples from cluster $A$, cluster $B$ and cluster $E$, at 2.27, 1.32 and $2.23 \mu \mathrm{g} \mathrm{N} \mathrm{g}^{-1} \mathrm{~d}^{-1}$, respectively (Fig. 6a). The rate of AOB was significantly higher in cluster $C$, with a value of $8.67 \mathrm{\mu g} \mathrm{N} \mathrm{g}^{-1} \mathrm{~d}^{-1}$ (Fig. 6b). The average activities of AOA and $A O B$ were both the maximum in EW with the values of 6.14 and $7.22 \mu \mathrm{g} \mathrm{g} \mathrm{g}^{-1} \mathrm{~d}^{-1}$. The average contributions of $A O A$ in were close to a half in EW, SW and RW, meanwhile the average contribution of AOA was only $25.40 \%$ in PF. 


\subsection{Group sorting of the observed $\mathrm{N}$ cycling microbial community}

The ordination of non-metric multidimensional scaling (NMDS) showed a clear sorting of samples according to the abundance of functional gene groups clustered with $95 \%$ confidence levels (Fig. 7). The NMDS analysis can more intuitively reflect the distribution characteristics of gene groups involved in the nitrogen cycle. The coordination of each point in the figure indicated comprehensive standardized assessment values of gene abundance in the tested soils/sediments (Liang et al. 2017). The distribution value is related to each element, where proximity to a certain element indicates a greater contribution of gene abundance to the comprehensive standardized assessment value. With the increase in AOA-amoA gene abundance, these samples clearly separated from other samples. However, samples with relatively higher AOB-amoA gene abundance still coupled with other samples. The group with relatively higher AOB$a m o A$ gene abundance overlapped with groups with a higher abundance of $a m x$, denitrifier, norA and even AOA-amoA. The activity of archaeal ammonia oxidation has a strong relationship with samples with relatively higher abundance of $A O A-a m o A$, while the activity of bacterial ammonia oxidation has a relationship with samples with higher abundance of AOB-amoA, amx and denitrification genes. In addition, the activity of archaeal ammonia oxidation was related to nitrite concentration, while the TOC value had a significant effect on the activity of bacterial ammonia oxidation. The distribution of archaeal and bacterial ammonia oxidation activity among all samples suggested that most samples with higher PAOA gathered in cluster $B$ with a higher abundance of AOA-amoA, in cluster A with a higher abundance of norA and in cluster $\mathrm{E}$ with a higher abundance of nitrate-reducing gene groups. Meanwhile, most samples with higher $\mathrm{PAOB}$ gathered in cluster $\mathrm{C}$ with a higher abundance of denitrification groups.

\subsection{Driving factors for potential archaeal and bacterial ammonia oxidizing activities}

We fitted a SEM to infer the direct and indirect effects of biotic and abiotic factors on potential activities and to advance our quantitative understanding of the molecular mechanism responsible for ammonia oxidation. The results showed that the control system for PAOA was different and simpler than that for PAOB. The results suggested that norA and AOA-amoA were the two most important driving microbial factors for PAOA (Fig. 8a). Meanwhile, $\mathrm{C} / \mathrm{N}$ was the most important driving environmental factor for PAOA. Furthermore, AOB-amoA acted directly on AOA-amoA. The TOC value acted directly on both norA and $\mathrm{C} / \mathrm{N}$, and nitrite concentration had a directly negative effect on $\mathrm{C} / \mathrm{N}(-0.250)$. However, the most important driving microbial factors for PAOB were $a m x$ and denitrifier groups (Fig. 8b). The most important driving environmental factors for PAOB were TOC value and ammonium concentration. In addition, $\mathrm{C} / \mathrm{N}$ had a directly negative effect on ammonium and a positive effect on TOC. Furthermore, the nitrate reducing group and $\mathrm{AOB}-\mathrm{amoA}$ affected $\mathrm{PAOB}$ indirectly via $a m x$, while the nitrate reducing group had another indirect effect on PAOB via the denitrifier group.

\section{Discussion}


A few literatures reported archaeal ammonia oxidation activity using inhibitors. (Zheng et al. 2013) suggested that archaeal ammonia oxidation activity ranged from 1.4 to $47.6 \mu \mathrm{g} \mathrm{N} \mathrm{g}^{-1}$ sediment d $\mathrm{d}^{-1}$ in Yangtze Estuary, while (Zhou et al. 2016) reported that archaeal ammonia oxidation activity ranged from 29.1 to $58.1 \mu \mathrm{g} \mathrm{N} \mathrm{g}^{-1}$ sediment $\mathrm{d}^{-1}$ in sediments from ancient canal. Our results were comparable to the rates from Yangtze Estuary, but lower than that of sediments from ancient canal. It may be caused by higher ammonia concentration in canal sediments which can promote ammonia oxidation activity.

There were significant differences in $A O A$ and $A O B$ activities in different types of wetlands. The $A O B$ activities in EW, PF, RW and SW were decreasing, while the AOA activities decreased in EW, RW, PF and $S W$ in turn. However, except for in PF, the average contributions of $A O A$ and $A O B$ were almost equal. In $S W$, the activities of $A O A$ and $A O B$ were significantly lower than other wetlands. It may be because the lowest nitrogen level in SW (Fig. 9). AOB was more competitive under high ammonia nitrogen conditions (French et al. 2012), while AOA was better under low ammonia nitrogen conditions (Martens-Habbena et al. 2009), thus the AOA contributed much more than AOB in PF where a great deal of nitrogenous fertilizer release for a good harvest.

Besides the influence of nitrogen concentration, $\mathrm{pH}, \mathrm{TOC}, \mathrm{C} / \mathrm{N}$ ratio and other environmental factors were also found to be important factors affecting the activity of $A O A$ and AOB. Environmental conditions had a great effect on microbial gene abundance and may cause changes in real-time process rates (Jusselme et al. 2016; Pester et al. 2012; Shrewsbury et al. 2016). The analysis of environmental effects on ammonia oxidation activity suggested that archaeal activity had a strong correlation with nitrate concentration. The positive relationship suggested that a higher abundance of AOA-amoA gene led to greater accumulation of nitrate. Meanwhile, bacterial activity had a strong correlation with ammonium concentration and TOC value (Fig. 8). As organic $\mathrm{C}$ and ammonium provided substrate and promoted nitrification for AOB (Forbes et al. 2009). In further SEM analysis, PAOA was mediated directly by the C/N ratio and indirectly by nitrite concentration and TOC value, while PAOB was mediated directly by ammonium concentration and TOC value and indirectly by $\mathrm{C} / \mathrm{N}$ ratio.

The NMDS analysis reflected that $A O B$ has close relationship with microbes involved in other nitrogen cycle processes, which is consistent with previous studies (Chen et al. 2012; Third et al. 2001). The samples in cluster $\mathrm{B}$, with a relatively higher abundance of the AOA-amoA gene than other clusters, obviously separated from other samples, except for partial overlap with cluster $D$ with a relatively higher abundance of AOB-amoA gene (Fig. 7), which suggested that the increase of AOA-amoA abundance may lead to a significantly different composition of functional genes in soil/sediment samples. However, samples in cluster $\mathrm{D}$ with a relatively higher abundance of $\mathrm{AOB}$-amoA gene overlapped more closely with other samples, which suggested that the increase in $A O B-a m o A$ abundance had only slight effect on the composition of functional genes for most samples. The results indicated that the change in AOA-amoA gene abundance may be more independent, while AOB-amoA may associate closely with the changes in the abundance of $a m x$ and denitrifier. 
In the six clusters, higher bacterial ammonia oxidation activities occurred in cluster $\mathrm{C}$, with a higher abundance of denitrifier, than in cluster $\mathrm{D}$, with a higher abundance of AOB-amoA gene (Fig. 10b). This suggested that the activity of $A O B$ may be easily influenced by other microorganisms. As for the distribution of PAOA, although some samples with higher archaeal ammonia oxidation activities occurred in cluster $\mathrm{A}$ with a higher abundance of norA and cluster $\mathrm{E}$ with a higher abundance of nitrate reducing groups, most samples were distributed in cluster B with a higher abundance of AOA-amoA gene (Fig. 10a), suggesting that the higher activity of AOA was strongly correlated with a higher abundance of the AOA-amoA gene. Previous results indicated that one nitrogen cycling process was comprehensively influenced by gene groups involved in other nitrogen cycle processes (Zhang et al. 2016, 2017). For instance, $\mathrm{N}_{2} \mathrm{O}$ production was also influenced by nar $\mathrm{G}$ and napA which were responsible for nitrate reduction. This study also demonstrated the coupling mechanism in nitrogen cycle. The activity of $A O B$ may be determined by several other functional gene groups and had little correlation with $A O B$ abundance. However, the activity of AOA was mostly controlled by itself, presenting a more stable, simpler regulation for the activity of AOA had little correlation with other functional gene groups.

Several studies reported the quantitative response of $\mathrm{N}$ transformation rate to the functional gene abundances. For instance, Wang et al. (2015) reported that $\mathrm{NH}_{4}{ }^{+} \mathrm{N}$ transformation rate was jointly determined by several functional genes, including amoA, nirS, nirk, anammox 16S rRNA and archaea 16S rRNA(Wang et al. 2015; Wang et al. 2015), and Pang reported that $\mathrm{NH}_{4}{ }^{+}-\mathrm{N}$ transformation rate was influenced by amoA, nirS and anammox 16S rRNA (Pang et al. 2015). This study further demonstrated the complex relationship between activity of $A O A / A O B$ and functional gene groups and the results of the SEM analysis showed the significant difference between the responses of $A O A$ and $A O B$. The pathway analysis indicated that PAOA was mainly correlated with absolute abundance of AOA-amoA and norA genes, while $\mathrm{PAOB}$ was mainly correlated with absolute abundance of denitrifier group and amx genes. The result of PAOA indicated that the activity of AOA was mostly defined by AOA-amoA abundance and was only slightly influenced by the abundance of norA gene. However, the strong association between PAOB and amx indicated close coupling of partial nitrification and ANAMMOX processes (Third et al. 2001; Zhu et al. 2011). The activity of AOA appeared to be more independent of other microbes, while the activity of $A O B$ varied closely with the fluctuations of other microbes.

The different effects of functional genes on $\mathrm{PAOA}$ and $\mathrm{PAOB}$ provide evidence for varying relative strengths of different microbial processes on their potential activities. The influence of norA on PAOA indicated that the archaeal ammonia oxidation potential was mainly limited by the assumption of nitrite through nitrite oxidation, consistent with the negative effect of nitrite concentration on PAOA via $\mathrm{C} / \mathrm{N}$ ratio (Fig. 8a). The strongest impacts of the abundance of denitrifier groups on PAOB suggested a limited role for nitrite reduction, which involves the complete reduction of nitrite into dinitrogen. The abundance of amx also exhibited a positive relationship with PAOB. The strong impacts of the abundance of amx and the denitrifier group on PAOB suggested coordination of these three nitrogen processes (ANAMMOX, denitrification and bacterial ammonia oxidation). AOB-amoA abundance had only a weak effect on PAOB 
via $a m x$, which further demonstrated that $A O B$ activity may rely on the abundance of other microbes rather than $\mathrm{AOB}$.

\section{Conclusions}

Aerobic ammonia oxidation is driven by both $A O A$ and $A O B$, but no clear results have been published about the response of $A O A$ and $A O B$ in terms of activity levels. This study reveals the differential driving factors for activity of ammonia-oxidizing archaea and bacteria. PAOA was mediated directly by the $\mathrm{C} / \mathrm{N}$ ratio and indirectly by nitrite concentration and TOC value, while PAOB was mediated directly by ammonium concentration and $\mathrm{TOC}$ value and indirectly by $\mathrm{C} / \mathrm{N}$ ratio. In addition, this study also demonstrated the coupling mechanism in nitrogen cycle. The activity of $A O B$ may be determined by several other functional gene groups and had little correlation with $\mathrm{AOB}$ abundance while the activity of AOA was mostly controlled by itself.

\section{Declarations}

\section{Acknowledgements}

The National Key Research and Development Project of China (No.2019YFC0409202), provided support for this study.

Code availability Not applicable.

Author Contributions C Wang Collected samples. C Wang, XF Zhu and SY Tang completed the determination and data analysis. XF Zhu and C Wang wrote the manuscript. GD Ji designed primary research.

Funding This research was funded by The National Key Research and Development Project of China (No.2019YFC0409202).

Data Availability The authors guarantee the availability of data and maretial.

\section{Declarations}

Conflicts of interest/Competing Interests The authors declare no conflict of interest.

Ethics Approval Not applicable.

Consent to Participate Not applicable.

Consent for Publication Not applicable.

\section{References}


Abell GCJ, Banks J, Ross DJ, Keane JP, Robert SS (2011) Effects of estuarine sediment hypoxia on nitrogen fluxes and ammonia oxidizer gene transcription. Fems Microbiology Ecology 75: 111-122

Baker SC, Ferguson SJ, Ludwig B, Page MD, Richter O, van Spanning R (1998) Molecular genetics of the genus Paracoccus: Metabolically versatile bacteria with bioenergetic flexibility. Microbiology and Molecular Biology Reviews 62, 1046.

Bouskill NJ, Eveillard D, Chien D, Jayakumar A (2012) Environmental factors determining ammoniaoxidizing organism distribution and diversity in marine environments. Environmental Microbiology 14: 714-729

Breuillin-Sessoms F, Venterea RT, Sadowsky MJ, Coulter JA, Clough TJ, Wang P (2017) Nitrification gene ratio and free ammonia explain nitrite and nitrous oxide production in urea-amended soils. Soil Biology \& Biochemistry 111: 143-153

Bru D, Sarr A, Philippot L (2007) Relative abundances of proteobacterial membrane-bound and periplasmic nitrate reductases in selected environments. Applied and Environmental Microbiology 73, 5971-5974.

Caffrey JM, Bano N, Kalanetra K, Hollibaugh JT (2007) Ammonia oxidation and ammonia-oxidizing bacteria and archaea from estuaries with differing histories of hypoxia. The ISME Journal 1: 660-662

Chen YP, Li S, Fang F, Guo JS, Zhang Q, Gao X (2012) Effect of inorganic carbon on the completely autotrophic nitrogen removal over nitrite (CANON) process in a sequencing batch biofilm reactor. Environmental Technology 33, 2611-2617

Erguder TH, Boon N, Wittebolle L, Marzorati M, Verstraete W (2009) Environmental factors shaping the ecological niches of ammonia-oxidizing archaea. Fems Microbiology Reviews 33, 855-869

Forbes MS, Broos K, Baldock JA, Gregg AL, Wakelin SA (2009): Environmental and edaphic drivers of bacterial communities involved in soil N-cycling. Australian Journal of Soil Research 47, 380-388

Fox J (2006) Structural equation modeling with the sem package in R. Structural Equation Modeling 13, 465-486

Francis CA, Roberts KJ, Beman JM, Santoro AE, Oakley BB (2005) Ubiquity and diversity of ammoniaoxidizing archaea in water columns and sediments of the ocean. Proceedings of the National Academy of Sciences of the United States of America 102, 14683-14688.

Glaser K, Hackl E, Inselsbacher E, Strauss J, Wanek W, Zechmeister-Boltenstern S, Sessitsch A (2010) Dynamics of ammonia-oxidizing communities in barley-planted bulk soil and rhizosphere following nitrate and ammonium fertilizer amendment. Fems Microbiology Ecology 74, 575-591 
Gleeson DB, Muller C, Banerjee S, Ma W, Siciliano SD, Murphy DV (2010) Response of ammonia oxidizing archaea and bacteria to changing water filled pore space. Soil Biology \& Biochemistry 42, 1888-1891

Godde M, Conrad R (1999) Immediate and adaptational temperature effects on nitric: oxide production and nitrous oxide release from nitrification and denitrification in two soils. Biology and Fertility of Soils $30,33-40$

Guo G, Deng H, Qiao M, Mu Y, Zhu Y (2011) Effect of pyrene on denitrification activity and abundance and composition of denitrifying community in an agricultural soil. Environmental Pollution 159, 1886-1895

Hatzenpichler R, Lebedeva EV, Spieck E, Stoecker K, Richter A, Daims H, Wagner M (2008) A moderately thermophilic ammonia-oxidizing crenarchaeote from a hot spring. Proceedings of the National Academy of Sciences of the United States of America 105, 2134-2139

Henry S, Baudoin E, Lopez-Gutierrez JC, Martin-Laurent F, Brauman A, Philippot L (2004) Quantification of denitrifying bacteria in soils by nirK gene targeted real-time PCR. Journal of Microbiologyical Methods 59, 327-335.

Hershberger SL (2001) Cause and Correlation in Biology: A User's Guide to Path Analysis, Structural Equations, and Causal Inference. Structural Equation Modeling 8, 646-649

Hou LJ, Zheng YL, Liu M, Gong J, Zhang XL, Yin GY, You L (2013) Anaerobic ammonium oxidation (anammox) bacterial diversity, abundance, and activity in marsh sediments of the Yangtze Estuary. Journal of Geophysical Research: Biogeosciences 118, 1237-1246

Jia Z, Conrad R (2009) Bacteria rather than Archaea dominate microbial ammonia oxidation in an agricultural soil. Environ Microbiol 11: 1658-1671. Environmental Microbiology 11, 1658-71

Jusselme MD, Saccone P, Zinger L, Faure M, Le Roux X, Guillaumaud N, Bernard L, Clement JC, Poly F (2016) Variations in snow depth modify N-related soil microbial abundances and functioning during winter in subalpine grassland. Soil Biology \& Biochemistry 92, 27-37

Kandeler E, Deiglmayr K, Tscherko D, Bru D, Philippot L (2006) Abundance of narG, nirS, nirK, and nosZ genes of denitrifying bacteria during primary successions of a glacier foreland. Applied and Environmental Microbiology 72, 5957-5962.

Könneke M, Bernhard AE, Jr DLT, Walker CB, Waterbury JB, StahI DA (2005) Isolation of an autotrophic ammonia-oxidizing marine archaeon. Nature 437, 543-6

Kowalchuk GA, Stephen JR (2001) Ammonia-oxidizing bacteria: A model for molecular microbial ecology. Annual Review of Microbiology 55, 485-529

Levy-Booth DJ, Prescott CE, Grayston SJ (2014) Microbial functional genes involved in nitrogen fixation, nitrification and denitrification in forest ecosystems. Soil Biology \& Biochemistry 75, 11-25 
Liang GN, Zhang B, Lin M, Wu SM, Hou H, Zhang J, Qian GR, Huang X, Zhou JZ (2017) Evaluation of heavy metal mobilization in creek sediment: Influence of RAC values and ambient environmental factors. Science of the Total Environment 607, 1339-1347

Lopez-Gutierrez JC, Henry S, Hallet S, Martin-Laurent F, Catroux G, Philippot L (2004) Quantification of a novel group of nitrate-reducing bacteria in the environment by real-time PCR. Journal of Microbiological Methods 57, 399-407.

Martens-Habbena W, Berube PM, Urakawa H, de la Torre JR, StahI DA (2009) Ammonia oxidation kinetics determine niche separation of nitrifying Archaea and Bacteria. Nature 461, 976-979

Nicol GW, Leininger S, Schleper C, Prosser JI (2008) The influence of soil pH on the diversity, abundance and transcriptional activity of ammonia oxidizing archaea and bacteria. Environmental Microbiology 10, 2966-2978

Pang YM, Zhang Y, Yan XJ, Ji GD (2015) Cold Temperature Effects on Long-Term Nitrogen Transformation Pathway in a Tidal Flow Constructed Wetland. Environmental Science \& Technology 49, 13550-13557

Pester M, Rattei T, Flechl S, Groengroeft A, Richter A, Overmann J, Reinhold-Hurek B, Loy A, Wagner M (2012) amoA-based consensus phylogeny of ammonia-oxidizing archaea and deep sequencing of amoA genes from soils of four different geographic regions. Environmental Microbiology 14, 525-539

Poly F, Wertz S, Brothier E, Degrange V (2008) First exploration of Nitrobacter diversity in soils by a PCR cloning-sequencing approach targeting functional gene nxrA. Fems Microbiology Ecology 63, 132-140.

Prosser Jl, Nicol GW (2008) Relative contributions of archaea and bacteria to aerobic ammonia oxidation in the environment. Environmental Microbiology 10, 2931-2941

Rotthauwe JH, Witzel KP, Liesack, W (1997) The ammonia monooxygenase structural gene amoA as a functional marker: Molecular fine-scale analysis of natural ammonia-oxidizing populations. Applied and Environmental Microbiology 63, 4704-4712.

Scala DJ, Kerkhof LJ (1998) Nitrous oxide reductase (nosZ) gene-specific PCR primers for detection of denitrifiers and three nosZ genes from marine sediments. Fems Microbiology Letters 162, 61-68.

Shrewsbury LH, Smith JL, Huggins DR, Carpenter-Boggs L, Reardon CL (2016) Denitrifier abundance has a greater influence on denitrification rates at larger landscape scales but is a lesser driver than environmental variables. Soil Biology \& Biochemistry 103, 221-231

Siles JA, Cajthaml T, Filipova A, Minerbi S, Margesin R (2017) Altitudinal, seasonal and interannual shifts in microbial communities and chemical composition of soil organic matter in Alpine forest soils. Soil Biology \& Biochemistry 112: 1-13 
Third KA, Sliekers AO, Kuenen JG, Jetten M (2001) The CANON system (completely autotrophic nitrogenremoval over nitrite) under ammonium limitation: Interaction and competition between three groups of bacteria. Systematic and Applied Microbiology 24: 588-596

Tsushima I, Kindaichi T, Okabe S (2007) Quantification of anaerobic ammonium-oxidizing bacteria in enrichment cultures by real-time PCR. Water Research 41, 785-794.

Venter JC et al. (2004) Environmental genome shotgun sequencing of the Sargasso Sea. Science 304, 6674

Wang B, Zhao J, Guo Z, Ma J, Xu H, Jia Z (2014) Differential contributions of ammonia oxidizers and nitrite oxidizers to nitrification in four paddy soils. The ISME Journal 9, 1062-1075

Wang HL, Ji GD, Bai XY, He CG (2015) Assessing nitrogen transformation processes in a trickling filter under hydraulic loading rate constraints using nitrogen functional gene abundances. Bioresource Technology 177: 217-223

Wendeborn S (2020) The chemistry, biology and modulation of ammonium nitrification in soil. Angewandte Chemie 132:2202-2223

Wootton JT (1994) Predicting direct and indirect effects- an integrated approach using experiments and path-analysis. Ecology 75, 151-165

Wuchter C, Abbas B, Coolen M, Herfort L, van Bleijswijk J, Timmers P, Strous M, Teira E, Herndl GJ, Middelburg JJ, Schouten S, Damste J (2006) Archaeal nitrification in the ocean. Proceedings of The National Academy of Science of the United States of America 103, 12317-12322

Ying J, Li X, Wang N, Lan Z, He J, Bai Y (2017) Contrasting effects of nitrogen forms and soil pH on ammonia oxidizing microorganisms and their responses to long-term nitrogen fertilization in a typical steppe ecosystem. Soil Biology \& Biochemistry 107, 10-18

Zhang M, Bai SH, Tang L, Zhang Y, Teng Y, Xu Z (2017) Linking potential nitrification rates, nitrogen cycling genes and soil properties after remediating the agricultural soil contaminated with heavy metal and fungicide. Chemosphere 184, 892-899

Zhang Y, Ji GD, Wang RJ (2016) Functional gene groups controlling nitrogen transformation rates in a groundwater-restoring denitrification biofilter under hydraulic retention time constraints. Ecological Engineering 87, 45-52

Zhang Y, Ji GD, Wang RJ (2017) Quantitative responses of nitrous oxide accumulation to genetic associations across a temperature gradient within denitrification biofilters. Ecological Engineering 102, 145-151 
Zheng Y, Hou L, Liu M, Lu M, Zhao H, Yin G, Zhou J (2013) Diversity, abundance, and activity of ammoniaoxidizing bacteria and archaea in Chongming eastern intertidal sediments. Applied Microbiology and Biotechnology 97, 8351-8363

Zhi W, Ji G (2014) Quantitative response relationships between nitrogen transformation rates and nitrogen functional genes in a tidal flow constructed wetland under $\mathrm{C} / \mathrm{N}$ ratio constraints. Water Research $64,32-41$

Zhou X, Zhang J, Li Y, Liu B, Chu J, Wang M, He Z (2016) Distribution characteristics of ammonia oxidizing microorganisms in rhizosphere sediments of cattail. Ecological Engineering 88, 99-111

Zhu GB, Wang SY, Wang Y, Wang CX, Risgaard-Petersen N, Jetten M, Yin CQ (2011) Anaerobic ammonia oxidation in a fertilized paddy soil. The ISME Journal 5, 1905-1912

\section{Tables}

Table 1 Basic properties of the samples 


\begin{tabular}{|c|c|c|c|c|c|c|c|}
\hline & Wetlands & $\begin{array}{l}\mathrm{NH}_{4}{ }^{+} \mathrm{N} \\
(\mathrm{mg} / \mathrm{kg})\end{array}$ & $\begin{array}{l}\mathrm{NO}_{2}{ }^{-}-\mathrm{N} \\
(\mathrm{mg} / \mathrm{kg})\end{array}$ & $\begin{array}{l}\mathrm{NO}_{3}{ }^{-}-\mathrm{N} \\
(\mathrm{mg} / \mathrm{kg})\end{array}$ & $\mathrm{pH}$ & $\begin{array}{l}\text { TOC } \\
\text { (\%) }\end{array}$ & $\begin{array}{l}\mathrm{TN} \\
(\mathrm{mg} / \mathrm{kg})\end{array}$ \\
\hline 1 & SW & 1.24 & 2.11 & 6.67 & 8.27 & 0.015 & 10.02 \\
\hline 2 & SW & 0.21 & 1.20 & 0.38 & 7.91 & 0.006 & 1.79 \\
\hline 3 & EW & 0.90 & 0.74 & 0.23 & 7.91 & 0.008 & 1.87 \\
\hline 4 & EW & 1.75 & 1.55 & 0.55 & 8.44 & 0.014 & 3.86 \\
\hline 5 & SW & 1.58 & 1.23 & 0.64 & 8.17 & 0.011 & 3.45 \\
\hline 6 & PF & 14.79 & 2.12 & 4.37 & 8.24 & 1.730 & 21.28 \\
\hline 7 & SW & 0.18 & 1.30 & 1.21 & 7.68 & 0.004 & 2.69 \\
\hline 8 & EW & 2.68 & 2.72 & 0.54 & 8.68 & 0.011 & 5.93 \\
\hline 9 & SW & 2.62 & 1.97 & 2.48 & 7.79 & 0.012 & 7.07 \\
\hline 10 & EW & 5.36 & 0.67 & 0.46 & 7.77 & 0.016 & 6.49 \\
\hline 11 & RW & 1.04 & 1.69 & 0.40 & 8.57 & 0.018 & 3.14 \\
\hline 12 & EW & 2.42 & 1.54 & 1.38 & 8.71 & 0.011 & 5.34 \\
\hline 13 & SW & 0.37 & 1.31 & 0.17 & 8.76 & 0.017 & 1.84 \\
\hline 14 & PF & 3.36 & 2.46 & 0.00 & 8.25 & 1.720 & 5.82 \\
\hline 15 & RW & 1.40 & 1.91 & 2.49 & 8.55 & 0.008 & 5.80 \\
\hline 16 & RW & 2.13 & 1.29 & 1.99 & 8.67 & 0.013 & 5.41 \\
\hline 17 & RW & 0.91 & 0.73 & 0.26 & 8.67 & 0.013 & 1.90 \\
\hline 18 & SW & 6.82 & 1.35 & 1.65 & 8.64 & 0.013 & 9.82 \\
\hline 19 & SW & 3.29 & 1.34 & 2.23 & 7.79 & 0.031 & 6.86 \\
\hline 20 & EW & 6.84 & 1.27 & 0.11 & 8.13 & 0.013 & 8.22 \\
\hline 21 & PF & 46.37 & 1.33 & 0.38 & 7.73 & 0.521 & 48.07 \\
\hline 22 & SW & 2.99 & 1.00 & 0.14 & 8.25 & 0.027 & 4.13 \\
\hline 23 & EW & 0.59 & 1.32 & 0.42 & 8.36 & 0.005 & 2.33 \\
\hline 24 & PF & 34.48 & 1.78 & 0.27 & 7.38 & 1.535 & 36.53 \\
\hline 25 & PF & 13.23 & 1.49 & 0.52 & 8.27 & 1.340 & 15.24 \\
\hline 26 & EW & 1.19 & 1.88 & 0.21 & 8.16 & 0.007 & 3.28 \\
\hline 27 & RW & 5.09 & 1.63 & 0.44 & 8.47 & 0.024 & 7.16 \\
\hline
\end{tabular}




\begin{tabular}{|llllllll|}
28 & EW & 1.54 & 0.57 & $/$ & 8.76 & 0.005 & 2.11 \\
\hline 29 & EW & 0.71 & 1.15 & 0.21 & 8.09 & 0.011 & 2.07 \\
\hline 30 & EW & 1.70 & 1.11 & 0.74 & 7.93 & 0.006 & 3.55 \\
\hline 31 & EW & 19.07 & 1.24 & 2.21 & 8.94 & 0.019 & 22.51 \\
\hline 32 & EW & 11.54 & 3.47 & 2.89 & 8.28 & 0.011 & 17.90 \\
\hline 33 & RW & 1.67 & 1.52 & 2.91 & 8.36 & 0.014 & 6.10 \\
\hline 34 & RW & 6.64 & 3.03 & 1.66 & 8.02 & 0.011 & 11.33 \\
\hline 35 & PF & 10.68 & 1.83 & 1.54 & 7.89 & 2.210 & 14.05 \\
\hline 36 & SW & 1.68 & 1.38 & 1.04 & 8.01 & 0.015 & 4.11 \\
\hline 37 & EW & 1.77 & 1.02 & 0.42 & 8.53 & 0.016 & 3.21 \\
\hline 38 & EW & 39.21 & 1.59 & 4.25 & 7.83 & 0.038 & 45.05 \\
\hline 39 & SW & 0.83 & 0.36 & 0.14 & 8.23 & 0.018 & 1.33 \\
\hline
\end{tabular}

Table 1 Basic properties of the samples 


\begin{tabular}{|llllllll|}
\hline & Wetlands & $\mathrm{NH}_{4}{ }^{+}-\mathrm{N}$ & $\mathrm{NO}_{2}{ }^{-} \mathrm{N}$ & $\mathrm{NO}_{3}{ }^{-} \mathrm{N}$ & $\mathrm{pH}$ & $\mathrm{TOC}$ & $\mathrm{TN}$ \\
& & $(\mathrm{mg} / \mathrm{kg})$ & $(\mathrm{mg} / \mathrm{kg})$ & $(\mathrm{mg} / \mathrm{kg})$ & & $(\%)$ & $(\mathrm{mg} / \mathrm{kg})$ \\
\hline 40 & EW & 0.27 & 0.03 & 0.12 & 8.63 & 0.025 & 0.42 \\
\hline 41 & RW & 5.90 & 1.76 & 0.43 & 7.94 & 0.035 & 8.09 \\
\hline 42 & EW & 2.91 & 2.11 & $/$ & 8.86 & 0.019 & 5.02 \\
\hline 43 & RW & 0.98 & 1.34 & 3.70 & 8.95 & 0.017 & 6.02 \\
\hline 44 & SW & 1.28 & 1.41 & 1.71 & 8.95 & 0.019 & 4.40 \\
\hline 45 & EW & 1.41 & 1.45 & $/$ & 9.06 & 0.026 & 2.86 \\
\hline 46 & EW & 4.94 & 12.90 & 8.51 & 8.17 & 0.020 & 26.36 \\
\hline 47 & RW & 1.58 & 0.44 & 3.83 & 8.29 & 0.018 & 5.85 \\
\hline 48 & SW & 0.90 & 0.51 & 1.28 & 7.87 & 0.015 & 2.69 \\
\hline 49 & RW & 1.74 & 0.32 & 0.50 & 8.33 & 0.026 & 2.56 \\
\hline 50 & EW & 0.74 & 0.07 & $/$ & 8.40 & 0.022 & 0.81 \\
\hline 51 & EW & 5.41 & 0.52 & 0.69 & 8.60 & 0.019 & 6.62 \\
\hline 52 & EW & 1.11 & 1.49 & 0.00 & 8.65 & 0.017 & 2.60 \\
\hline 53 & EW & 1.11 & 1.28 & 0.92 & 8.34 & 0.015 & 3.30 \\
\hline 54 & EW & 0.09 & 1.25 & 0.77 & 8.29 & 0.012 & 2.11 \\
\hline 55 & EW & 6.24 & 0.62 & 0.16 & 8.25 & 0.017 & 7.02 \\
\hline 56 & EW & 1.17 & 1.40 & $/$ & 8.07 & 0.006 & 2.58 \\
\hline 57 & EW & 9.07 & 1.03 & 0.31 & 8.10 & 0.021 & 10.42 \\
\hline 58 & EW & 0.17 & 1.52 & 1.08 & 8.39 & 0.007 & 2.77 \\
\hline 59 & EW & 31.63 & 1.38 & 3.19 & 7.70 & 0.012 & 36.20 \\
\hline 60 & EW & 3.21 & 2.42 & 0.35 & 7.65 & 0.008 & 5.97 \\
\hline 61 & SW & 1.47 & 1.64 & 1.67 & 8.13 & 0.005 & 4.78 \\
\hline 62 & SW & 0.63 & 1.27 & 0.71 & 7.78 & 0.004 & 2.61 \\
\hline & & & & & & & \\
\hline
\end{tabular}

Table 2 Primers of target genes used in the qPCR analysis 


\begin{tabular}{|c|c|c|c|}
\hline Target gene & Prime name & Primer sequence $\left(5^{\prime}-3^{\prime}\right)$ & Reference \\
\hline \multirow[t]{2}{*}{ AOA-amoA } & Arch-amoAF & STA ATG GTC TGG CTT AGA CG & \multirow[t]{2}{*}{ Francis et al.,2005 } \\
\hline & Arch-amoAR & GCG GCC ATC CAT CTG TAT GT & \\
\hline \multirow[t]{2}{*}{ AOB-amoA } & amoA-1F & GGG GTT TCT ACT GGT & \multirow[t]{2}{*}{ Rotthauwe et al.,1997 } \\
\hline & $a m o A-2 R$ & CCC CTC KGS AAA GCC TTC & \\
\hline \multirow[t]{2}{*}{ norA } & F1norA & CAGACCGACGTGTGCGAAAG & \multirow[t]{2}{*}{ Poly et al., 2008} \\
\hline & R1norA & TCYACAAGGAACGGAAGGTC & \\
\hline \multirow[t]{2}{*}{$A m x$} & AMX809F & GCCGTAAACGATGGGCACT & \multirow[t]{2}{*}{ Tsushima et al.,2007 } \\
\hline & AMX1066R & AACGTCTCACGACACGAGCTG & \\
\hline \multirow[t]{2}{*}{ napA } & napAV17m & TGGACVATGGGYTTYAAYC & \multirow[t]{2}{*}{ Bru et al., 2007} \\
\hline & napA4r & ACYTCRCGHGCVGTRCCRCA & \\
\hline \multirow[t]{2}{*}{ narG } & narG1960m2f & TA(CT)GT(GC)GGGCAGGA(AG)AAACTG & \multirow{2}{*}{$\begin{array}{l}\text { Lopez-Gutierrez } \\
\text { et al., } 2004\end{array}$} \\
\hline & narG2050m2r & CGTAGAAGAAGCTGGTGCTGTT & \\
\hline \multirow[t]{2}{*}{ nirk } & nirk876 & ATYGGCGGVAYGGCGA & \multirow[t]{2}{*}{ Henry et al.,2004 } \\
\hline & nirK1040 & GCCTCGATCAGRTTRTGGTT & \\
\hline \multirow[t]{2}{*}{ nirs } & nirSCd3aF & AACGYSAAGGARACSGG & \multirow[t]{2}{*}{ Kandeler et al.,2006 } \\
\hline & nirSR3cd & GASTTCGGRTGSGTCTTSAYGAA & \\
\hline \multirow[t]{2}{*}{ qnorB } & qnorB2F & GGNCAYCARGGNTAYGA & \multirow[t]{2}{*}{ Baker et al.,1998 } \\
\hline & qnorB5R & ACCCANAGRTGNACNACCCACCA & \\
\hline \multirow[t]{2}{*}{ nos $Z$} & nosZ1527F & CGCTGTTCHTCGACAGYCA & \multirow[t]{2}{*}{ Scala and Kerkhof, 1998} \\
\hline & nosZ1773R & ATRTCGATCARCTGBTCGTT & \\
\hline
\end{tabular}

Table 3 Protocols and parameters of target genes used in APCR analysis 


\begin{tabular}{|c|c|}
\hline Target gene & Programs \\
\hline AOA-amoA & 5 min at $94^{\circ} \mathrm{C}, 40$ cycles of $30 \mathrm{~s}$ at $94^{\circ} \mathrm{C}, 60 \mathrm{~s}$ at $53^{\circ} \mathrm{C}$, and $60 \mathrm{~s}$ at $72^{\circ} \mathrm{C}$ (plate read) \\
\hline AOB-amoA & 5 min at $94^{\circ} \mathrm{C}, 40$ cycles of $30 \mathrm{~s}$ at $94^{\circ} \mathrm{C}, 56 \mathrm{~s}$ at $60^{\circ} \mathrm{C}$, and $60 \mathrm{~s}$ at $72^{\circ} \mathrm{C}$ (plate read) \\
\hline norA & $10 \mathrm{~min}$ at $95^{\circ} \mathrm{C}, 40$ cycles of $15 \mathrm{~s}$ at $95^{\circ} \mathrm{C}, 30 \mathrm{~s}$ at $58^{\circ} \mathrm{C}$, and $30 \mathrm{~s}$ at $72^{\circ} \mathrm{C}$ (plate read) \\
\hline Amx & 10 min at $95^{\circ} \mathrm{C}, 40$ cycles of $15 \mathrm{~s}$ at $95^{\circ} \mathrm{C}, 45 \mathrm{~s}$ at $56^{\circ} \mathrm{C}$, and $30 \mathrm{~s}$ at $72^{\circ} \mathrm{C}$ (plate read) \\
\hline napA & $10 \mathrm{~min}$ at $95^{\circ} \mathrm{C}, 40$ cycles of $15 \mathrm{~s}$ at $95^{\circ} \mathrm{C}, 50 \mathrm{~s}$ at $56^{\circ} \mathrm{C}$, and $30 \mathrm{~s}$ at $72^{\circ} \mathrm{C}$ (plate read) \\
\hline narG & 10 min at $95^{\circ} \mathrm{C}, 40$ cycles of $15 \mathrm{~s}$ at $95^{\circ} \mathrm{C}, 45 \mathrm{~s}$ at $58^{\circ} \mathrm{C}$, and $30 \mathrm{~s}$ at $72^{\circ} \mathrm{C}$ (plate read) \\
\hline nirk & $10 \mathrm{~min}$ at $95^{\circ} \mathrm{C}, 40$ cycles of $15 \mathrm{~s}$ at $95^{\circ} \mathrm{C}, 40 \mathrm{~s}$ at $64^{\circ} \mathrm{C}$, and $30 \mathrm{~s}$ at $72^{\circ} \mathrm{C}$ (plate read) \\
\hline nirs & 10 min at $95^{\circ} \mathrm{C}, 40$ cycles of $15 \mathrm{~s}$ at $95^{\circ} \mathrm{C}, 30 \mathrm{~s}$ at $57^{\circ} \mathrm{C}$, and $30 \mathrm{~s}$ at $72^{\circ} \mathrm{C}$ (plate read) \\
\hline qnorB & $10 \mathrm{~min}$ at $95^{\circ} \mathrm{C}, 40$ cycles of $15 \mathrm{~s}$ at $95^{\circ} \mathrm{C}, 30 \mathrm{~s}$ at $56^{\circ} \mathrm{C}$, and $30 \mathrm{~s}$ at $72^{\circ} \mathrm{C}$ (plate read) \\
\hline nos $Z$ & $10 \mathrm{~min}$ at $95^{\circ} \mathrm{C}, 40$ cycles of $15 \mathrm{~s}$ at $95^{\circ} \mathrm{C}, 50 \mathrm{~s}$ at $58^{\circ} \mathrm{C}$, and $30 \mathrm{~s}$ at $72^{\circ} \mathrm{C}$ (plate read) \\
\hline
\end{tabular}

\section{Figures}




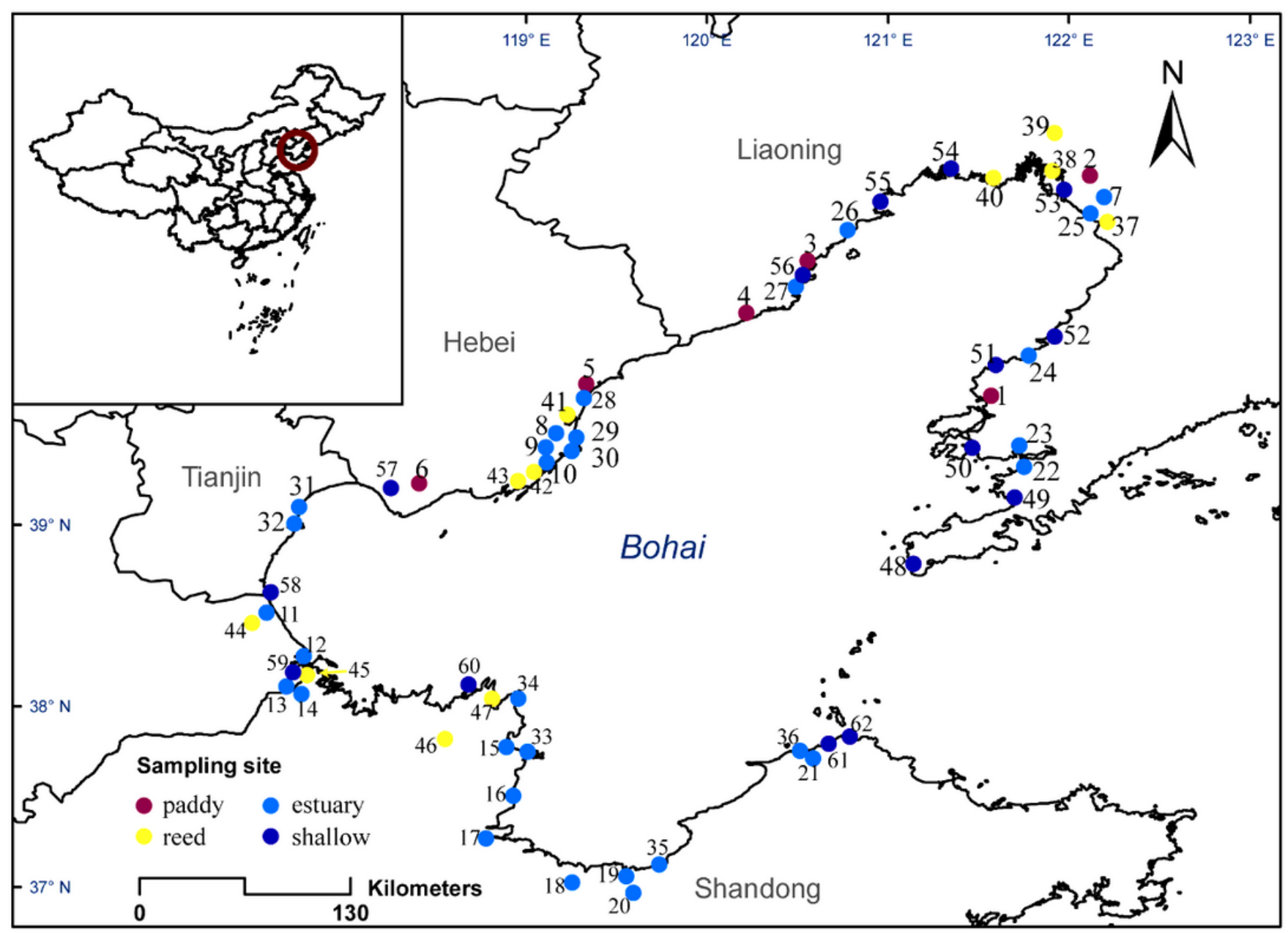

Figure 1

Sampling sites in coastal wetlands around Bohai area. Note: The designations employed and the presentation of the material on this map do not imply the expression of any opinion whatsoever on the part of Research Square concerning the legal status of any country, territory, city or area or of its authorities, or concerning the delimitation of its frontiers or boundaries. This map has been provided by the authors. 


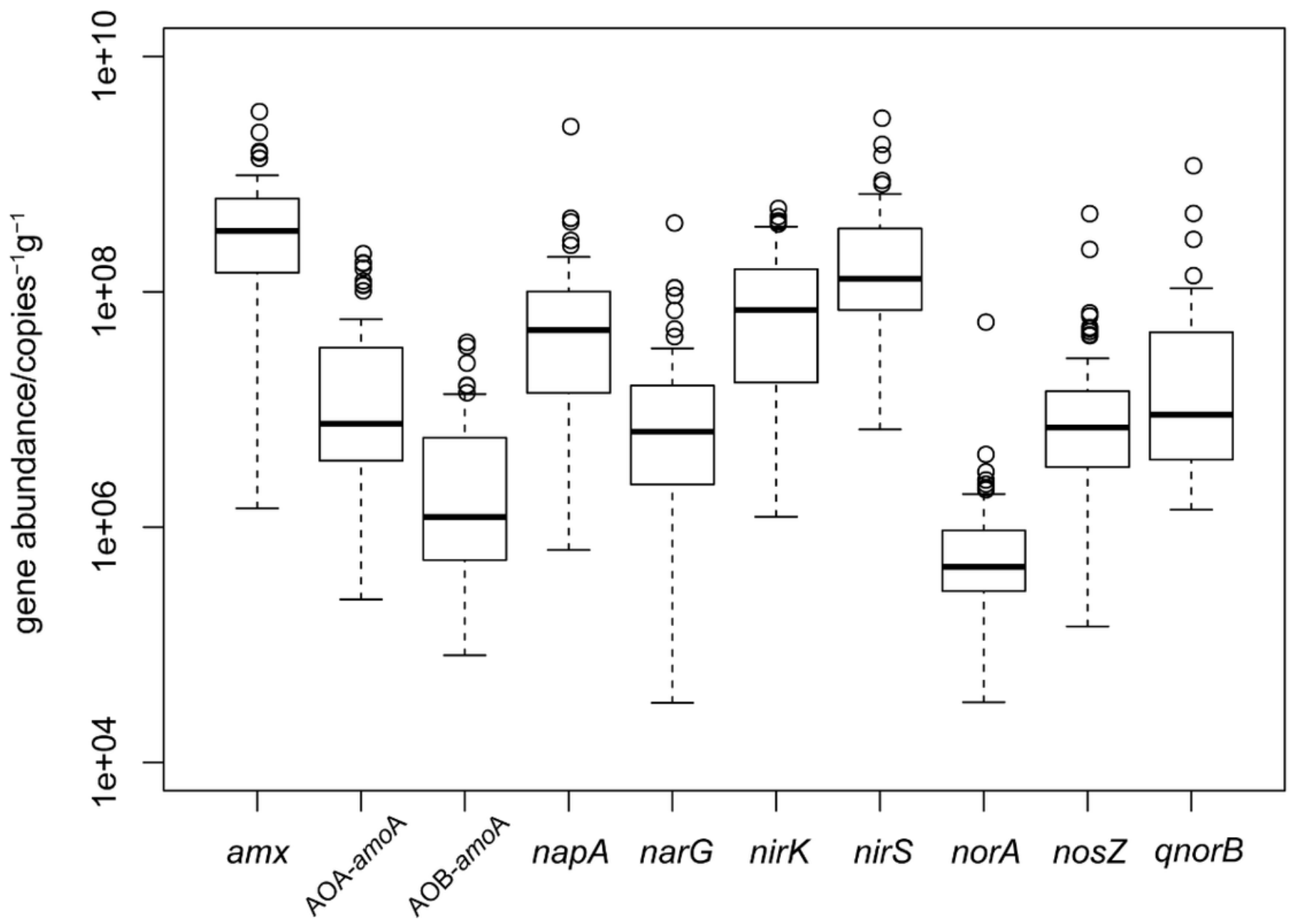

Figure 2

Abundance of amx, AOA-amoA, AOB-amoA, napA, narG, nirk, nirS, norA, nosZ and qnorB. The upper and lower boundaries of each box indicate the 75th and 25th percentile, respectively, and the mid-line marks the median values, while dots indicate outliers. 


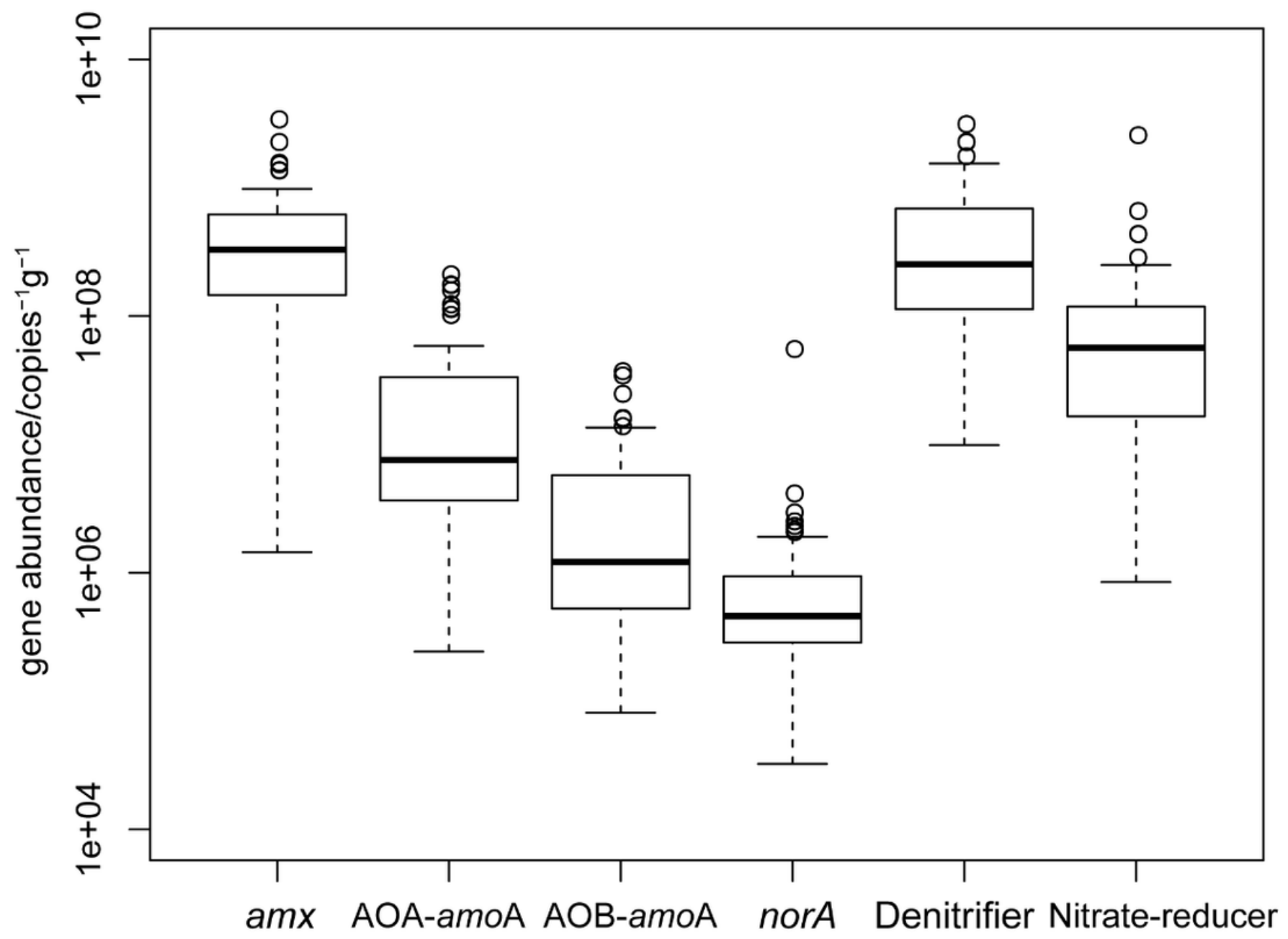

Figure 3

Abundance of functional gene groups involved in each nitrogen cycle process. 


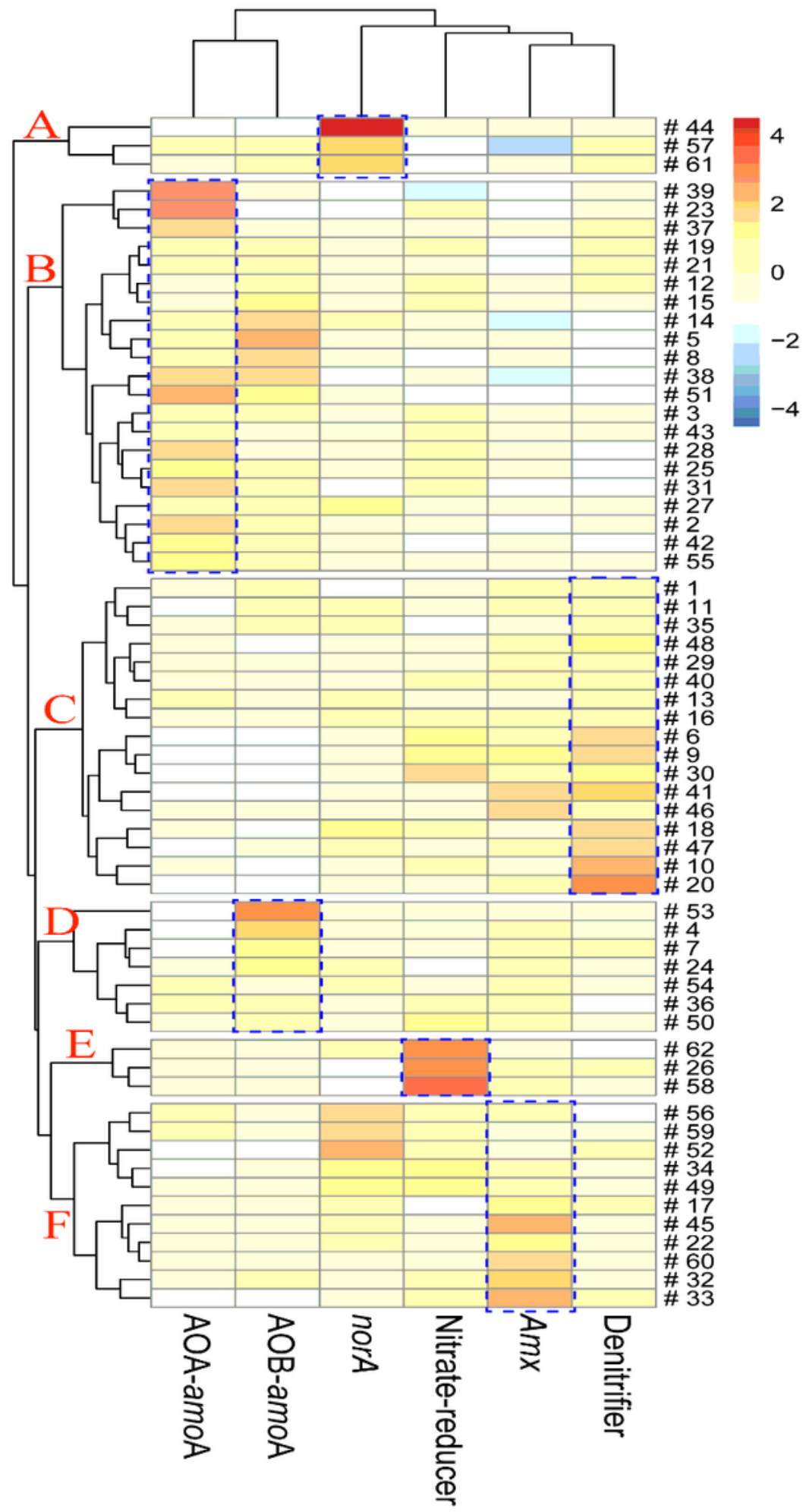

Figure 4

Heat map and cluster analysis of all samples based on the abundance of functional gene groups involved in each nitrogen cycle process. All samples could be divided into 6 clusters, with relatively higher abundance of certain groups. Clusters A, B, C, D, E and F stand for relatively higher abundances of norA, AOA-amoA, denitrifier, AOB-amoA, nitrate-reducer and amx, respectively. 

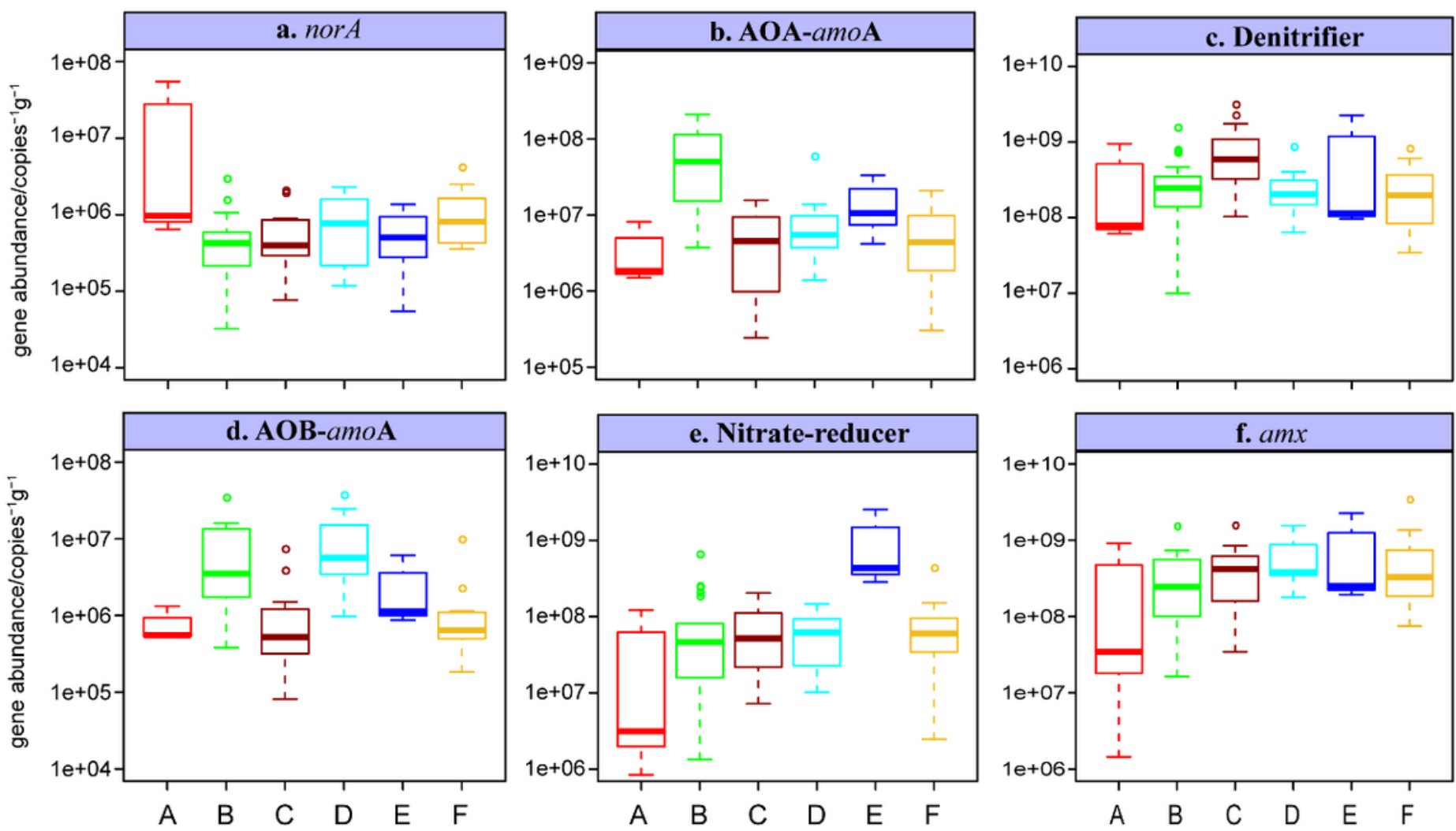

\section{Cluster}

\section{Figure 5}

Abundance of functional gene groups in different clusters. (a) norA, (b) AOA-amoA, (c) Denitrifier, (d) AOBamoA gene, (e) Nitrate-reducer, (f) amx. The upper and lower boundaries of each box indicate the 75th and 25th percentile, respectively, and the mid-line marks the median values, while dots indicate outliers. Clusters $A, B, C, D, E$ and $F$ stand for samples with relatively higher abundances of norA, AOA-amoA, denitrifier, AOB-amoA, nitrate-reducer and amx, respectively. 

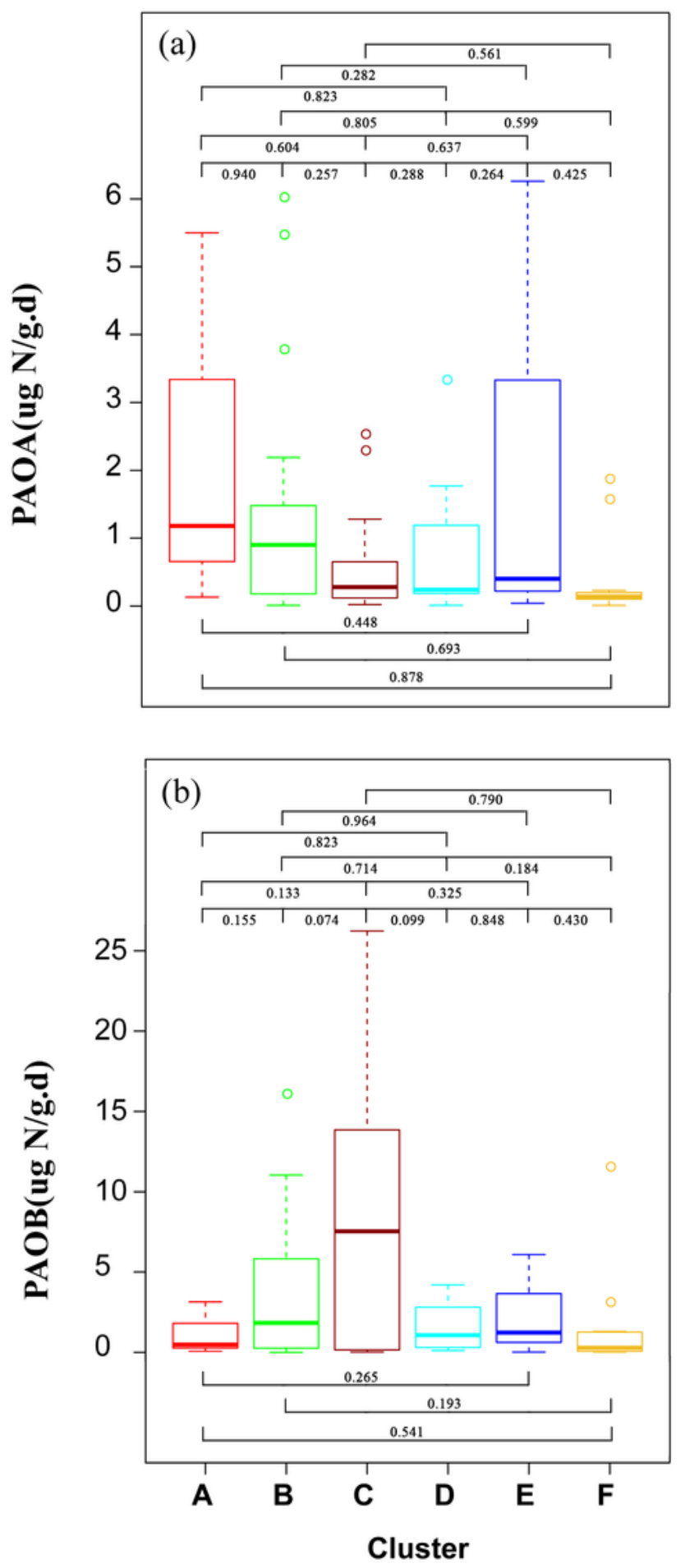

Figure 6

Potential activity of archaeal ammonia oxidation (PAOA) (a) and bacterial ammonia oxidation (PAOB) (b) in 6 clusters. Clusters $A, B, C, D, E$ and $F$ stand for samples with relatively higher abundances of norA, AOA-amoA, denitrifier, AOB-amoA, nitrate-reducer and amx, respectively. 


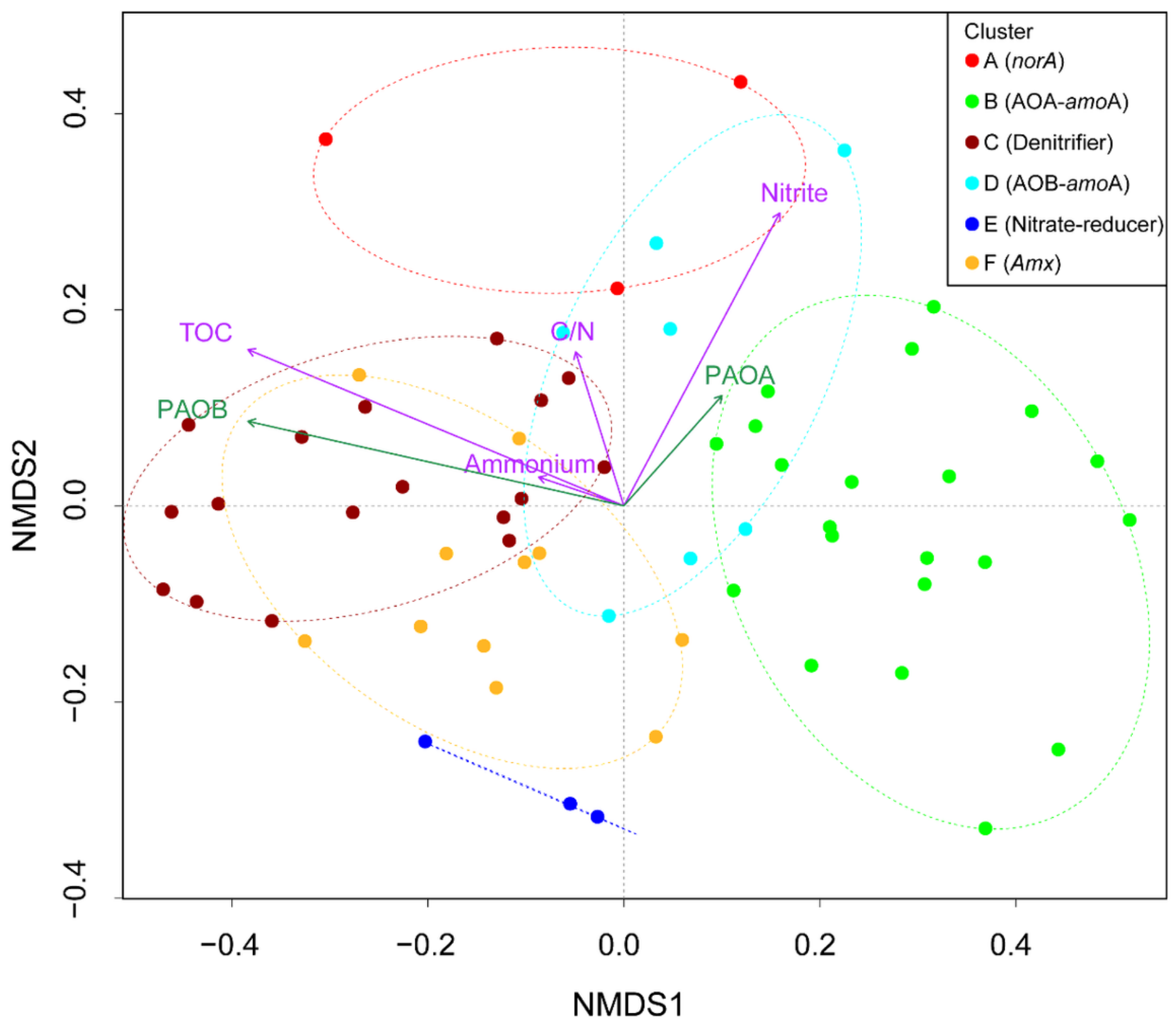

Figure 7

Non-metric multidimensional scaling (NMDS) analysis based on various functional gene groups involved in nitrogen cycling. The significance of vector fits was determined using permutation tests $(n=1000)$ at the $\mathrm{P}=0.05$ level. Ellipses indicates $95 \%$ confidence interval for replicates. Different colours represent different groups dominated by certain gene groups. 

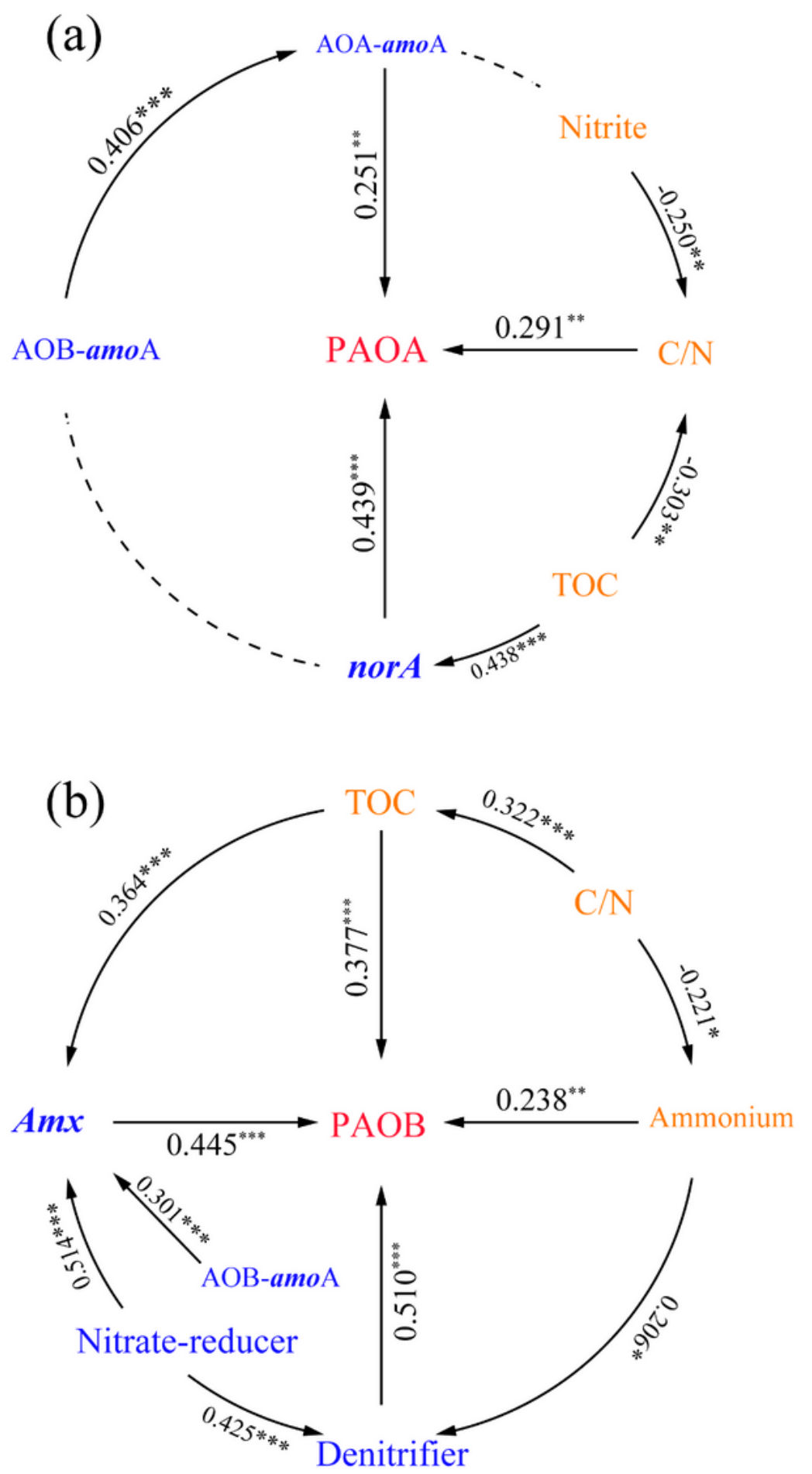

\section{Figure 8}

Structure equation model (SEM) describing the direct and indirect contributions of biotic and abiotic factors to potential activity of AOA (PAOA) (a) and AOB (PAOB) (b). Single-pointed arrows indicate causal paths. Path coefficients are standardized, and all solid arrows indicate significant paths at a significance level of 0.05 . 


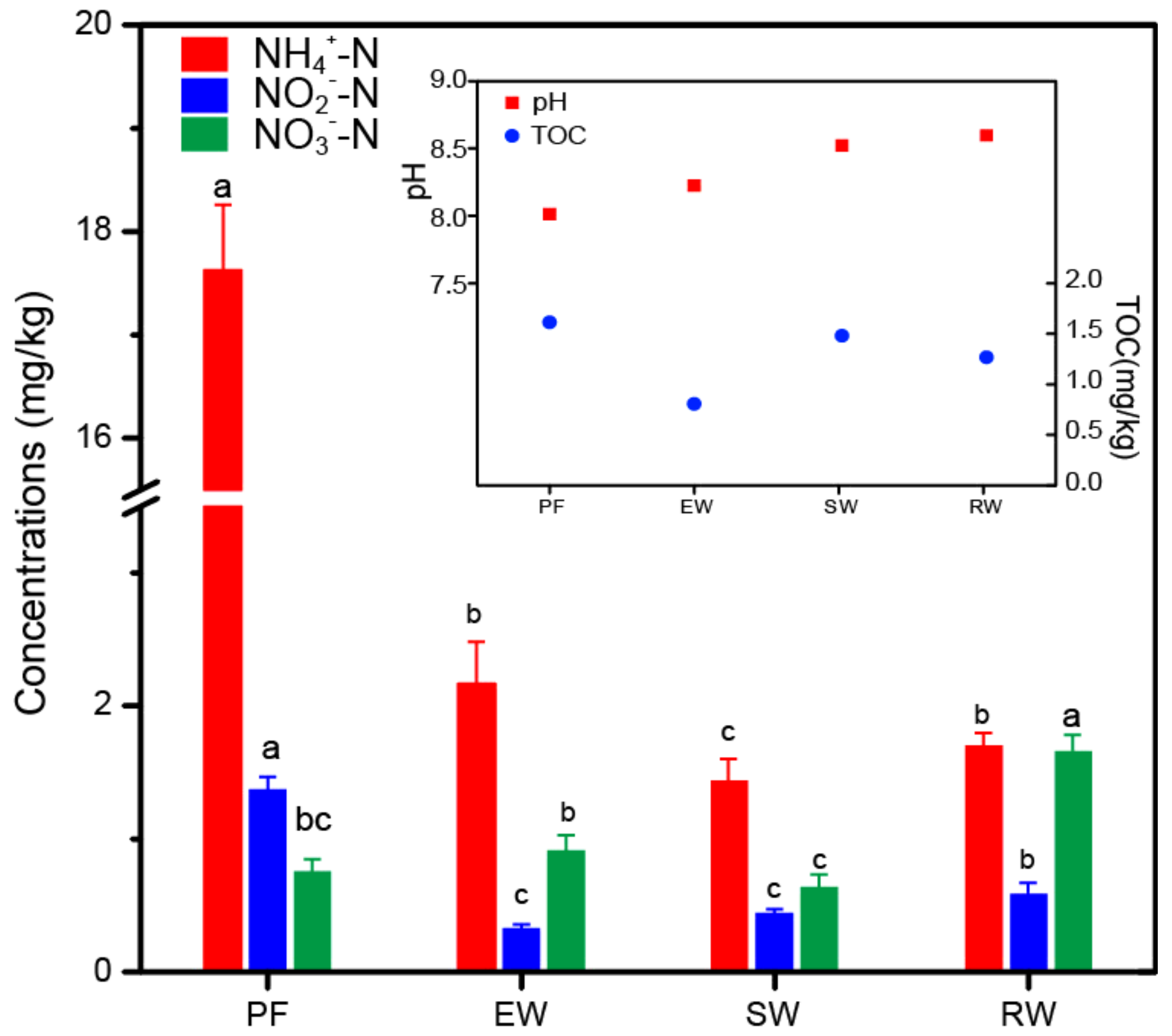

Figure 9

The concentrations of $\mathrm{NH} 4+, \mathrm{NO} 2-$ and NO3- and the $\mathrm{pH}$ value and $\mathrm{TOC}$ of four wetlands. The data are presented as the mean \pm standard error $(n=3)$. The different letters above the columns indicate a significant difference $(P<0.05)$ based on the analysis of variance. 

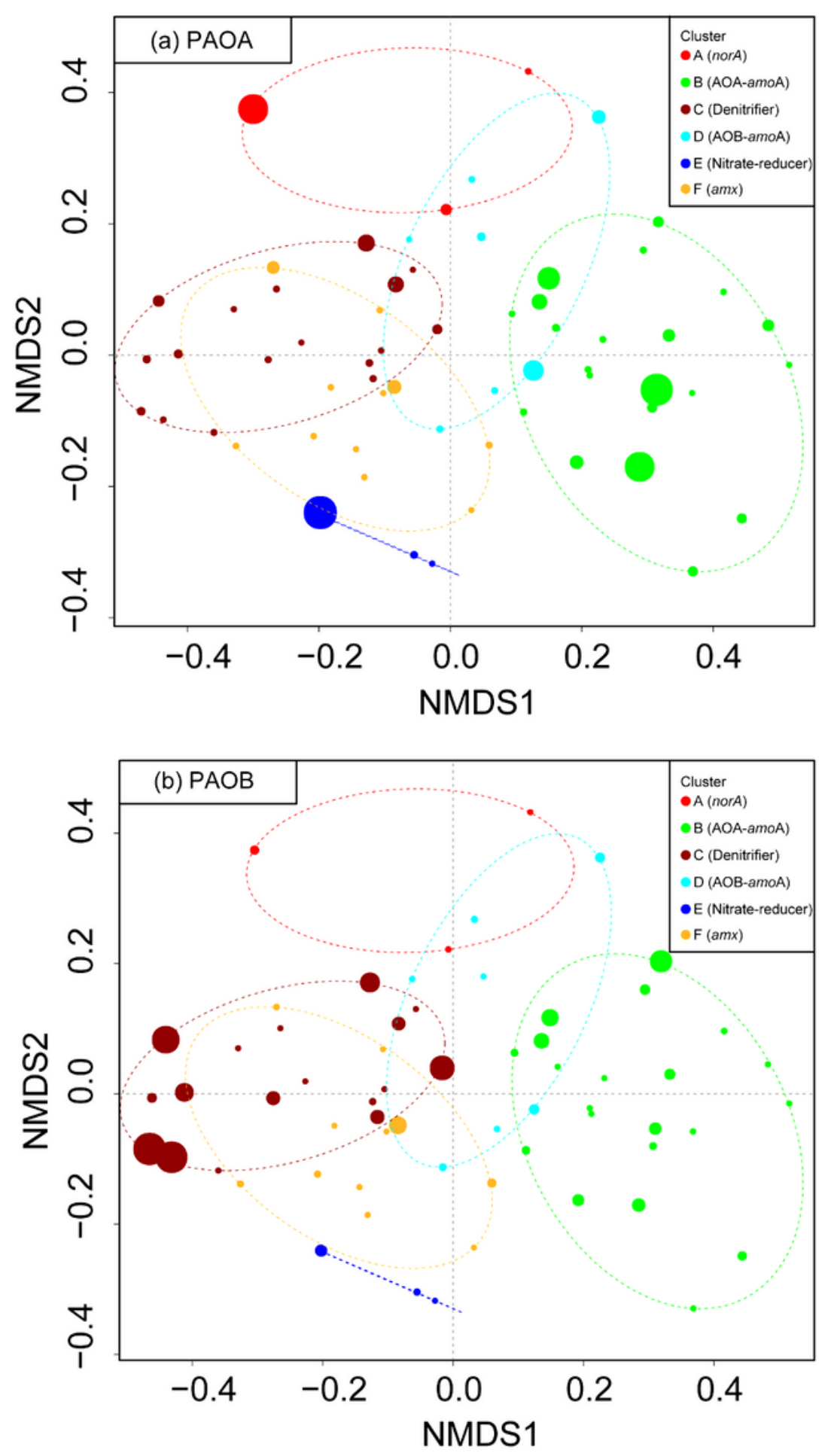

Figure 10

Relative activity of $A O A(a)$ and $A O B(b)$ in all samples. The circle size represents relative value of corresponding activity in all samples. 